\title{
JOURNAL OF GLACIOLOGY
}

\author{
INDEX Vol. 47 No. 156-159, 2001
}

Ablation:

Detection of snowmelt regions on the Greenland ice sheet using diurnal backscatter change, 539-547

The seasonal cycle of sublimation at Halley, Antarctica, 1-8

Significant marine-ice accumulation in the ablation zone beneath an Antarctic ice shelf, 359-368

Accumulation:

Correspondence, 160-162

The elevation history of ice streams and the spatial accumulation pattern along the Siple Coast of West Antarctica inferred from groundbased radar data from three inter-ice-stream ridges, 303-313

Interannual variability of elevation on the Greenland ice sheet: effects of firn densification, and establishment of a multi-century benchmark, 369-377

A mean net accumulation pattern derived from radioactive layers and radar soundings on Austfonna, Nordaustlandet, Svalbard, 555-566

Aizen, V. B., see Kreutz, K. J. and others

Alley, R. B., see Ensminger, S. L. and others

Alley, R. B., see Spencer, M. K. and others

Alley, R. B., see Waddington, E. D. and others

Allison, I., see Xiao Cunde and others

Amundsen Sea (Antarctica):

Surface properties and processes of perennial Antarctic sea ice in summer, 613-625

Amundsenisen (Antarctica):

A high-altitude snow chemistry record from Amundsenisen, Dronning Maud Land, Antarctica, 489-496

Anderson, J. B., see Wellner, J. S. and others

Anderson, P. S., see King, J. C. and others

Andes:

Glacier-climate interaction at low latitudes, 195-204

Small glaciers disappearing in the tropical Andes: a case-study in Bolivia: Glaciar Chacaltaya $\left(16^{\circ} \mathrm{S}\right), 187-194$

Antarctica:

Blue-ice areas in Antarctica derived from NOAA AVHRR satellite data, 325-334

Correspondence, 159-160, 160-162

Coupled marine-ice-sheet/Earth dynamics using a dynamically consistent ice-sheet model and a self-gravitating viscous Earth model, 258-270

Crevasse patterns at the onset to Ice Stream B, West Antarctica, 29-36

Detailed observations of the rippled surface of Antarctic blue-ice areas, 387-396

Distribution of glacial geomorphic features on the Antarctic continental shelf and correlation with substrate: implications for ice behavior, 397-411

Dynamical processes involved in the retreat of marine ice sheets, 271-282

The elevation history of ice streams and the spatial accumulation pattern along the Siple Coast of West Antarctica inferred from ground-based radar data from three inter-ice-stream ridges, 303-313

Ephemeral grounding as a signal of ice-shelf change, 71-77

Evidence for rapid retreat and mass loss of Thwaites Glacier, West Antarctica, 213-222

Formation processes of basal ice at Hamna Glacier, Sôya Coast, East Antarctica, inferred by detailed co-isotopic analyses, 223-231

A high-altitude snow chemistry record from Amundsenisen, Dronning Maud Land, Antarctica, 489-496

Internal ice-sheet radar layer profiles and their relation to reflection mechanisms between Dome $\mathrm{C}$ and the Transantarctic Mountains, $205-212$

Investigations of an "ice-plain" in the mouth of Pine Island Glacier, Antarctica, 51-57

Meteorological conditions over Antarctic blue-ice areas and their influence on the local surface mass balance, 37-50
Methanesulphonate in the firn of King George Island, Antarctica, 589-594 Modeling giant-iceberg drift under the influence of sea ice in the Weddell Sea, Antarctica, $452-460$

Post-stagnation behavior in the upstream regions of Ice Stream C, West Antarctica, 283-294

Preliminary firn-densification model with 38-site dataset, 671-676

Review. The West Antarctic ice sheet: behavior and environment, 521-522

The seasonal cycle of sublimation at Halley, Antarctica, 1-8

Significant marine-ice accumulation in the ablation zone beneath an Antarctic ice shelf, 359-368

Surface properties and processes of perennial Antarctic sea ice in summer, 613-625

Transmission of stress between an ice stream and interstream ridge, 433-440

Arck, M. and D. Scherer, (paper: A physically based method for correcting temperature data measured by naturally ventilated sensors over snow) 665-670

Austfonna (Svalbard):

A mean net accumulation pattern derived from radioactive layers and radar soundings on Austfonna, Nordaustlandet, Svalbard, 555-566

Austre Okstindbreen (Norway):

Correspondence, 517-518

Firn-line detection on Austre Okstindbreen, Norway, with airborne multipolarization SAR, 251-257

The isotopic record at an alpine glacier and its implications for local climatic changes and isotopic homogenization processes, 147-151

Austria:

Glacier-climate interaction at low latitudes, 195-204

Bakaninbreen (Svalbard):

Mechanical and hydraulic properties of till beneath Bakaninbreen, Svalbard, $167-175$

Thermally controlled glacier surging, 527-538

Bareiss, J., see Haas, C. and others

Basal conditions:

Basal-crevasse-fill origin of laminated debris bands at Matanuska Glacier, Alaska, U.S.A., 412-422:

Correspondence, 159-160

Distributed shear of subglacial till due to Coulomb slip, 481-488:

Implications of till deformation on glacier dynamics, 123-134:

Mapping thermal and hydrological conditions beneath a polythermal glacier with radio-echo sounding, 232-242:

Mechanical and hydraulic properties of till beneath Bakaninbreen, Svalbard, 167-175:

Subglacial deformation: evidence from microfabric studies of particles and voids in till from the upper Ürümqi river valley, Tien Shan, China, 607-612

Bellingshausen Sea (Antarctica):

Surface properties and processes of perennial Antarctic sea ice in summer, $613-625$

Benn, D., see Warren, C. and others

Benn, D. I., S. Wiseman and K. A. Hands, (paper: Growth and drainage of supraglacial lakes on the debris-mantled Ngozumpa Glacier, Khumbu Himal, Nepal) 626-638

Bindschadler, R. A., see Price, S. F. and others

Bintanja, R. and C. H. Reijmer, (paper: Detailed observations of the rippled surface of Antarctic blue-ice areas) 387-396

Bintanja, R. and C. H. Reijmer, (paper: Meteorological conditions over Antarctic blue-ice areas and their influence on the local surface mass balance) $37-50$

Birkeland, K.W., (paper: Spatial patterns of snow stability throughout a small mountain range) $176-186$ 
Björnsson, H., H. Rott, S. Gudmundsson, A. Fischer, A. Siegel and M. T. Gudmundsson, (paper: Glacier-volcano interactions deduced by SAR interferometry) $58-70$

Black Rapids Glacier (U.S.A.):

Implications of till deformation on glacier dynamics, 123-134

Blatter, H., see Vieli, A. and others

Blue ice:

Blue-ice areas in Antarctica derived from NOAA AVHRR satellite data, 325-334

Detailed observations of the rippled surface of Antarctic blue-ice areas 387-396

Meteorological conditions over Antarctic blue-ice areas and their influence on the local surface mass balance, 37-50

Bolivia:

Anomalous heat and mass budget of Glaciar Zongo, Bolivia, during the 1997/98 El Niño year, 21-28

Small glaciers disappearing in the tropical Andes: a case-study in Bolivia: Glaciar Chacaltaya $\left(16^{\circ} \mathrm{S}\right), 187-194$

Bolzan, J. F., see Waddington, E. D. and others

Bondesan, A., see Khazendar, A. and others

Bradley, R. S., see Braun, C. and others

Braun, C., D. R. Hardy and R. S. Bradley, (correspondence: Recent recession of a small plateau ice cap, Ellesmere Island, Canada) 154

Calving:

Buoyancy-driven lacustrine calving, Glaciar Nef, Chilean Patagonia, 135-146

Flow dynamics of tidewater glaciers: a numerical modelling approach, 595-606

Short-term flow dynamics of a retreating tidewater glacier: LeConte Glacier, Alaska, U.S.A., 567-578

Tidewater glacier beds: insights from iceberg debris in Kongsfjorden, Svalbard, 295-302

Canada:

Abrupt glacier motion and reorganization of basal shear stress following the establishment of a connected drainage system, 472-480

Correspondence, 154

Mapping thermal and hydrological conditions beneath a polythermal glacier with radio-echo sounding, 232-242

Thermally controlled glacier surging, 527-538

Cecil, L. DeW., see Kreutz, K. J. and others

Chacaltaya Glaciar (Bolivia):

Small glaciers disappearing in the tropical Andes: a case-study in Bolivia: Glaciar Chacaltaya $\left(16^{\circ} \mathrm{S}\right), 187-194$

Chemistry:

Correspondence, 155-156, 519-520

Enhancement of glacial solute fluxes in the proglacial zone of a polythermal glacier, 378-386

A high-altitude snow chemistry record from Amundsenisen, Dronning Maud Land, Antarctica, 489-496

Methanesulphonate in the firn of King George Island, Antarctica, 589-594

A new ice-core record from Lomonosovfonna, Svalbard: viewing the 1920-97 data in relation to present climate and environmental conditions, 335-345

Oxygen isotopic and soluble ionic composition of a shallow firn core, Inilchek glacier, central Tien Shan, 548-554

Chile:

Buoyancy-driven lacustrine calving, Glaciar Nef, Chilean Patagonia, $135-146$

China:

Longitudinal variations in cross-section morphology along a glacial valley: a case-study from the Tien Shan, China, 243-250

Subglacial deformation: evidence from microfabric studies of particles and voids in till from the upper Ürümqi river valley, Tien Shan, China, 607-612

Clarke, G. K. C., see Kavanaugh, J. L.

Climate:

Correspondence, $160-162$
Estimating South Cascade Glacier (Washington, U.S.A.) mass balance from a distant radiosonde and comparison with Blue Glacier, 579-588 Glacier-climate interaction at low latitudes, 195-204

A new ice-core record from Lomonosovfonna, Svalbard: viewing the 1920-97 data in relation to present climate and environmental conditions, 335-345

On the characterization of glacier response by a single time-scale, 659-664

Oxygen isotopic and soluble ionic composition of a shallow firn core, Inilchek glacier, central Tien Shan, 548-554

Quantifying the effects of climate and surface change on glacier mass balance, 649-658

The surges of Variegated Glacier, Alaska, U.S.A., and their connection to climate and mass balance, $351-358$

Colle Gnifetti (Switzerland):

Modelling heat flow in a cold, high-altitude glacier: interpretation of measurements from Colle Gnifetti, Swiss Alps, 314-324

Collins Ice Cap (Antarctica):

Methanesulphonate in the firn of King George Island, Antarctica, 589-594

Conway, H., see Rasmussen, L. A.

Cooper, R. J., see Wadham, J. L. and others

Copland, L. and M. Sharp, (paper: Mapping thermal and hydrological conditions beneath a polythermal glacier with radio-echo sounding) 232-242

Corr, H. F. J., C. S. M. Doake, A. Jenkins and D. G. Vaughan, (paper: Investigations of an "ice-plain" in the mouth of Pine Island Glacier, Antarctica) $51-57$

Correspondence:

10 years of mass-balance measurements along a transect near Kangerlussuaq, central West Greenland, 157-158

A reason for resin, 153

Comments on "Calculating basal thermal zones beneath the Antarctic ice sheet" by Wilch and Hughes, 159-160

Complexity of the climatic regime over the Lambert Glacier basin of the East Antarctic ice sheet: firn-core evidences, 160-162

Evidence of the Kuwaiti oil fires in the Dasuopu glacier ice core, central Himalaya, 519-520

Fracturing and sediment deposition at the glacier surface by jökulhlaups: a common occurrence, $517-518$

Recent 180 years oxalate $\left(\mathrm{C}_{2} \mathrm{O}_{4}{ }^{2-}\right)$ records recovered from the Mount Everest ice core: some environmental implications, 155-156

Recent recession of a small plateau ice cap, Ellesmere Island, Canada, 154

Crevasses:

Crevasse patterns at the onset to Ice Stream B, West Antarctica, 29-36

Creyts, T. T., see Spencer, M. K. and others

Cuffey, K. M., (paper: Interannual variability of elevation on the Greenland ice sheet: effects of firn densification, and establishment of a multi-century benchmark) 369-377

Cui Zhijiu, see Li Yingkui and others

Cui Zhijiu, see Yi Chaolu

Dai Dongsheng, see Han Jiankang and others

Dasuopu glacier (China):

Correspondence. Evidence of the Kuwaiti oil fires in the Dasuopu glacier ice core, central Himalaya, 519-520

Denby, B., see Greuell, W. and others

Descloitres, M., see Ramírez, E. and others

Dini, M., see Khazendar, A. and others

Doake, C. S. M., see Corr, H. F. J. and others

Dome C (Antarctica):

Internal ice-sheet radar layer profiles and their relation to reflection mechanisms between Dome $\mathrm{C}$ and the Transantarctic Mountains, 205-212

Drilling:

Correspondence, 153

Duan Keqin, see Kang Shichang and others

Echelmeyer, K. A., see Elsberg, D. H. and others 
Echelmeyer, K. A., see O'Neel, S. and others

Echelmeyer, K. A., see Truffer, M. and others

Eiken, T., see Pinglot, J. F. and others

Eisen, O., W. D. Harrison and C. F. Raymond, (paper: The surges of Variegated Glacier, Alaska, U.S.A., and their connection to climate and mass balance) $351-358$

El Niño:

Anomalous heat and mass budget of Glaciar Zongo, Bolivia, during the $1997 / 98$ El Niño year, 21-28

Elsberg, D. H., W. D. Harrison, K. A. Echelmeyer and R. M. Krimmel, (paper: Quantifying the effects of climate and surface change on glacier mass balance) 649-658

Energy balance:

Anomalous heat and mass budget of Glaciar Zongo, Bolivia, during the 1997/98 E1 Niño year, 21-28

Ensminger, S. L., R. B. Alley, E. B. Evenson, D. E. Lawson and G. J. Larson, (paper: Basal-crevasse-fill origin of laminated debris bands at Matanuska Glacier, Alaska, U.S.A.) 412-422

Erratum:

Buoyancy-driven lacustrine calving, Glaciar Nef, Chilean Patagonia, 348

Evenson, E. B., see Ensminger, S. L. and others

Far East Rongbuk Glacier (China): Correspondence, 155-156

Finsterwalderbreen (Svalbard):

Enhancement of glacial solute fluxes in the proglacial zone of a polythermal glacier, 378-386

Firn:

Cold firn and ice of high-altitude glaciers in the Alps: measurements and distribution modelling, 85-96

Interannual variability of elevation on the Greenland ice sheet: effects of firn densification, and establishment of a multi-century benchmark, 369-377

Methanesulphonate in the firn of King George Island, Antarctica, 589-594

Oxygen isotopic and soluble ionic composition of a shallow firn core, Inilchek glacier, central Tien Shan, 548-554

Preliminary firn-densification model with 38-site dataset, 671-676

Fischer, A., see Björnsson, H. and others

Floating ice:

Frazil-ice entrainment of sediment: large-tank laboratory experiments, 461-471

Modeling giant-iceberg drift under the influence of sea ice in theWeddell Sea, Antarctica, 452-460

Review. Ice in the ocean, 523

Significant marine-ice accumulation in the ablation zone beneath an Antarctic ice shelf, 359-368

Surface properties and processes of perennial Antarctic sea ice in summer, 613-625

Fowler, A. C., T. Murray and F. S. L. Ng, (paper: Thermally controlled glacier surging) 527-538

Francou, B., see Ramírez, E. and others

Francou, B., see Wagnon, P. and others

Frauenfelder, R., see Suter, S. and others

Frazil ice:

Frazil-ice entrainment of sediment: large-tank laboratory experiments, $461-471$

Fujita, S., see Siegert, M. J.

Funk, M., see Lüthi, M. P.

Funk, M., seeVieli, A. and others

Gallaire, R., see Ramírez, E. and others

Gauer, P., (paper: Numerical modeling of blowing and drifting snow in Alpine terrain) $97-110$

Gerasimoff, M. D. and C. P. Wake, (correspondence: A reason for resin) 153
Glacial geology:

Distribution of glacial geomorphic features on the Antarctic continental shelf and correlation with substrate: implications for ice behavior, 397-411

Longitudinal variations in cross-section morphology along a glacial valley: a case-study from the Tien Shan, China, 243-250

Review. Deformation of glacial materials, 163-164

Subglacial deformation: evidence from microfabric studies of particles and voids in till from the upper Ürümqi river valley, Tien Shan, China, 607-612

Tidewater glacier beds: insights from iceberg debris in Kongsfjorden, Svalbard, 295-302

Glacier flow:

Abrupt glacier motion and reorganization of basal shear stress following the establishment of a connected drainage system, 472-480

Flow dynamics of tidewater glaciers: a numerical modelling approach, 595-606

Ice-divide flow at Hans Tausen Iskappe, North Greenland, from surface movement data, 78-84

Implications of till deformation on glacier dynamics, 123-134

Potential for stratigraphic folding near ice-sheet centers, 639-648

Short-term flow dynamics of a retreating tidewater glacier: LeConte Glacier, Alaska, U.S.A., 567-578

Spatial patterns of glacier motion during a high-velocity event: Haut Glacier d'Arolla, Switzerland, 9-20

Transmission of stress between an ice stream and interstream ridge, 433-440

Glacier hydrology:

Abrupt glacier motion and reorganization of basal shear stress following the establishment of a connected drainage system, 472-480

Correspondence, 517-518

Enhancement of glacial solute fluxes in the proglacial zone of a polythermal glacier, 378-386

Mapping thermal and hydrological conditions beneath a polythermal glacier with radio-echo sounding, 232-242

Glacier variations:

Correspondence, 154

Coupled marine-ice-sheet/Earth dynamics using a dynamically consistent ice-sheet model and a self-gravitating viscous Earth model, 258-270

Dynamical processes involved in the retreat of marine ice sheets, 271-282

Evidence for rapid retreat and mass loss of Thwaites Glacier, West Antarctica, 213-222

Short-term flow dynamics of a retreating tidewater glacier: LeConte Glacier, Alaska, U.S.A., 567-578

Small glaciers disappearing in the tropical Andes: a case-study in Bolivia: Glaciar Chacaltaya $\left(16^{\circ} \mathrm{S}\right), 187-194$

Terminus behavior and response time of North Cascade glaciers, Washington, U.S.A., 497-506

Glaciers:

Anomalous heat and mass budget of Glaciar Zongo, Bolivia, during the 1997/98 El Niño year, 21-28

Basal-crevasse-fill origin of laminated debris bands at Matanuska Glacier, Alaska, U.S.A., 412-422

Buoyancy-driven lacustrine calving, Glaciar Nef, Chilean Patagonia, 135-146

Characteristics of a crater glacier at Ushkovsky volcano, Kamchatka, Russia, as revealed by the physical properties of ice cores and borehole thermometry, 423-432

Cold firn and ice of high-altitude glaciers in the Alps: measurements and distribution modelling, 85-96

Correspondence, 517-518

Crevasse patterns at the onset to Ice Stream B, West Antarctica, 29-36

Enhancement of glacial solute fluxes in the proglacial zone of a polythermal glacier, 378-386

Ephemeral grounding as a signal of ice-shelf change, 71-77

Estimating South Cascade Glacier (Washington, U.S.A.) mass balance from a distant radiosonde and comparison with Blue Glacier, 579-588

Evidence for rapid retreat and mass loss of Thwaites Glacier, West Antarctica, 213-222

Firn-line detection on Austre Okstindbreen, Norway, with airborne multipolarization SAR, 251-257

Flow dynamics of tidewater glaciers: a numerical modelling approach, 595-606

Glacier-climate interaction at low latitudes, 195-204

Glacier-volcano interactions deduced by SAR interferometry, 58-70

Growth and drainage of supraglacial lakes on the debris-mantled Ngozumpa Glacier, Khumbu Himal, Nepal, 626-638 
Investigations of an "ice-plain" in the mouth of Pine Island Glacier, Antarctica, 51-57

Mapping thermal and hydrological conditions beneath a polythermal glacier with radio-echo sounding, 232-242

Mechanical and hydraulic properties of till beneath Bakaninbreen, Svalbard, 167-175

Modelling heat flow in a cold, high-altitude glacier: interpretation of measurements from Colle Gnifetti, Swiss Alps, 314-324

Multi-model photogrammetric analysis of the 1990s surge of Sortebræ, East Greenland, 677-687

On the characterization of glacier response by a single time-scale, 659-664

Oxygen isotopic and soluble ionic composition of a shallow firn core, Inilchek glacier, central Tien Shan, 548-554

Post-stagnation behavior in the upstream regions of Ice Stream C, West Antarctica, 283-294

Quantifying the effects of climate and surface change on glacier mass balance, 649-658

Short-term flow dynamics of a retreating tidewater glacier: LeConte Glacier, Alaska, U.S.A., 567-578

Small glaciers disappearing in the tropical Andes: a case-study in Bolivia: Glaciar Chacaltaya $\left(16^{\circ} \mathrm{S}\right), 187-194$

Spatial patterns of glacier motion during a high-velocity event: Haut Glacier d'Arolla, Switzerland, 9-20

Terminus behavior and response time of North Cascade glaciers, Washington, U.S.A., 497-506

The elevation history of ice streams and the spatial accumulation pattern along the Siple Coast of West Antarctica inferred from ground-based radar data from three inter-ice-stream ridges, 303-313

The surges of Variegated Glacier, Alaska, U.S.A., and their connection to climate and mass balance, 351-358

The isotopic record at an alpine glacier and its implications for local climatic changes and isotopic homogenization processes, 147-151

Thermally controlled glacier surging, 527-538

Transmission of stress between an ice stream and interstream ridge, 433-440

Glasser, N. F. and M. J. Hambrey, (paper: Tidewater glacier beds: insights from iceberg debris in Kongsfjorden, Svalbard) 295-302

Greenland:

Correspondence, 157-158

Ice-divide flow at Hans Tausen Iskappe, North Greenland, from surface movement data, $78-84$

Multi-model photogrammetric analysis of the 1990s surge of Sortebræ, East Greenland, 677-687

Preliminary firn-densification model with 38-site dataset, 671-676

Greenland Ice Sheet:

Detection of snowmelt regions on the Greenland ice sheet using diurnal backscatter change, 539-547

Greenland ice-sheet mass-balance distribution: a variance analysis of existing field data, 441-451

Interannual variability of elevation on the Greenland ice sheet: effects of firn densification, and establishment of a multi-century benchmark, 369-377

Potential for stratigraphic folding near ice-sheet centers, 639-648

Grenzgletscher (Switzerland):

Cold firn and ice of high-altitude glaciers in the Alps: measurements and distribution modelling, 85-96

Greuell, W., B. Denby, R. S.W. van de Wal and J. Oerlemans, (correspondence: 10 years of mass-balance measurements along a transect near Kangerlussuaq, central West Greenland) 157-158

Grubengletscher (Switzerland):

Prevention of outburst floods from periglacial lakes at Grubengletscher, Valais, Swiss Alps, 111-122

Gudmundsson, M. T., see Björnsson, H. and others

Gudmundsson, S., see Björnsson, H. and others

Gundestrup, N., see Hvidberg, C. S. and others

Guneriussen, T., see König, M. and others

Guérin, R., see Ramírez, E. and others

Haas, C., D. N. Thomas and J. Bareiss, (paper: Surface properties and processes of perennial Antarctic sea ice in summer) 613-625

Haeberli, W., see Suter, S. and others

Haeberli, W., A. Kääb, D. Vonder Mühll and P. Teysseire, (paper: Prevention of outburst floods from periglacial lakes at Grubengletscher, Valais, Swiss Alps) 111-122
Hagen, J. O., see Isaksson, E. and others

Hagen, J. O., see Pinglot, J. F. and others

Hambrey, M. J., see Glasser, N. F.

Han Jiankang, Xie Zichu, Zhang Xinping, Dai Dongsheng, P. A. Mayewski and M. S. Twickler, (paper: Methanesulphonate in the firn of King George Island, Antarctica) 589-594

Hands, K. A., see Benn, D. I. and others

Hans Tausen Iskappe (Greenland):

Ice-divide flow at Hans Tausen Iskappe, North Greenland, from surface movement data, $78-84$

Hansbreen (Svalbard):

Flow dynamics of tidewater glaciers: a numerical modelling approach, 595-606

Hardy, D. R., see Braun, C. and others

Harrison, S., see Warren, C. and others

Harrison, W. D., see Eisen, O. and others

Harrison, W. D., see Elsberg, D. H. and others

Harrison, W. D., see Truffer, M. and others

Harrison, W. D., D. H. Elsberg, K. A. Echelmeyer and R. M. Krimmel, (paper: On the characterization of glacier response by a single timescale) 659-664

Haut Glacier d'Arolla (Switzerland): Spatial patterns of glacier motion during a high-velocity event: Haut Glacier d'Arolla, Switzerland, 9-20

He Yuanqing, W. H. Theakstone, Shi Yafeng and Yao Tandong, (paper: The isotopic record at an alpine glacier and its implications for local climatic changes and isotopic homogenization processes) 147-151

Hedlund, C., see Pelto, M. S.

Hellmer, H. H., see Lichey, C.

Himalaya:

Correspondence, 155-156, 519-520

Growth and drainage of supraglacial lakes on the debris-mantled Ngozumpa Glacier, Khumbu Himal, Nepal, 626-638

Hindmarsh, R. C. A. and E. Le Meur, (paper: Dynamical processes involved in the retreat of marine ice sheets) 271-282

Hindmarsh, R. C. A., see Le Meur, E.

Hintereisferner (Austria):

Glacier-climate interaction at low latitudes, 195-204

Hodgkins, R., see Wadham, J. L. and others

Hoelzle, M., see Suter, S. and others

Hughes, T. J., (review: Alley, Richard B. and Robert A. Bindschadler, eds. 2001. The West Antarctic ice sheet: behavior and environment) 521-522

Hulbe, C. L., see Price, S. F. and others

Hvidberg, C. S., K. Keller, N. Gundestrup and P. Jonsson, (paper: Icedivide flow at Hans Tausen Iskappe, North Greenland, from surface movement data) $78-84$

Ice cores:

A mean net accumulation pattern derived from radioactive layers and radar soundings on Austfonna, Nordaustlandet, Svalbard, 555-566

A new ice-core record from Lomonosovfonna, Svalbard: viewing the 1920-97 data in relation to present climate and environmental conditions, 335-345

Characteristics of a crater glacier at Ushkovsky volcano, Kamchatka, Russia, as revealed by the physical properties of ice cores and borehole thermometry, 423-432

Correspondence, 155-156, 160-162, 519-520

Potential for stratigraphic folding near ice-sheet centers, 639-648

Review. Alley, Richard B. 2000. The two-mile time machine: ice cores, abrupt climate change, and our future, 524

Ice properties:

An analytical approach to deformation of anisotropic ice-crystal aggregates, $507-516$ 
Ice sheets:

Coupled marine-ice-sheet/Earth dynamics using a dynamically consistent ice-sheet model and a self-gravitating viscous Earth model, 258-270

Dynamical processes involved in the retreat of marine ice sheets, 271-282

Ice shelves:

Ephemeral grounding as a signal of ice-shelf change, $71-77$

Significant marine-ice accumulation in the ablation zone beneath an Antarctic ice shelf, 359-368

Ice Stream B (Antarctica), now Whillans Ice Stream:

Crevasse patterns at the onset to Ice Stream B, West Antarctica, 29-36

Post-stagnation behavior in the upstream regions of Ice Stream C, West Antarctica, 283-294

The elevation history of ice streams and the spatial accumulation pattern along the Siple Coast of West Antarctica inferred from ground-based radar data from three inter-ice-stream ridges, 303-313

Transmission of stress between an ice stream and interstream ridge, 433-440

Post-stagnation behavior in the upstream regions of Ice Stream C, West Antarctica, 283-294

Ice Stream C (Antarctica):

The elevation history of ice streams and the spatial accumulation pattern along the Siple Coast of West Antarctica inferred from ground-based radar data from three inter-ice-stream ridges, 303-313

Ice Stream D (Antarctica):

The elevation history of ice streams and the spatial accumulation pattern along the Siple Coast of West Antarctica inferred from ground-based radar data from three inter-ice-stream ridges, 303-313

Ice Stream E (Antarctica):

The elevation history of ice streams and the spatial accumulation pattern along the Siple Coast of West Antarctica inferred from ground-based radar data from three inter-ice-stream ridges, 303-313

Ice thickness:

Investigations of an "ice-plain" in the mouth of Pine Island Glacier, Antarctica, $51-57$

Icebergs:

Modeling giant-iceberg drift under the influence of sea ice in the Weddell Sea, Antarctica, $452-460$

Tidewater glacier beds: insights from iceberg debris in Kongsfjorden, Svalbard, 295-302

Iceland:

Glacier-volcano interactions deduced by SAR interferometry, $58-70$

Iizuka, Y., H. Satake, T. Shiraiwa and R. Naruse, (paper: Formation processes of basal ice at Hamna Glacier, Sôya Coast, East Antarctica, inferred by detailed co-isotopic analyses) 223-231

Inilchek glacier (Kyrgyzstan):

Oxygen isotopic and soluble ionic composition of a shallow firn core, Inilchek glacier, central Tien Shan, 548-554

Instruments:

Correspondence, 153

A physically based method for correcting temperature data measured by naturally ventilated sensors over snow, $665-670$

Interferometry:

Evidence for rapid retreat and mass loss of Thwaites Glacier, West Antarctica, 213-222

Glacier-volcano interactions deduced by SAR interferometry, $58-70$

Irian Jaya (New Guinea):

Glacier-climate interaction at low latitudes, 195-204

Isaksson, E., V. Pohjola, T. Jauhiainen, J. Moore, J.-F. Pinglot, R. Vaikmäe, R. S.W. van de Wal, J. O. Hagen, J. Ivask, L. Karlöf, T. Martma, H. A. J. Meijer, R. Mulvaney, M. Thomassen and M. R. van den Broeke, (paper: A new ice-core record from Lomonosovfonna, Svalbard: viewing the 1920-97 data in relation to present climate and environmental conditions) $335-345$

Isaksson, E., W. Karlén, P. Mayewski, M. Twickler and S. Whitlow, (paper: A high-altitude snow chemistry record from Amundsenisen, Dronning Maud Land, Antarctica) 489-496

Isotopes:

Correspondence, 519-520
The isotopic record at an alpine glacier and its implications for local climatic changes and isotopic homogenization processes, 147-151

A mean net accumulation pattern derived from radioactive layers and radar soundings on Austfonna, Nordaustlandet, Svalbard, 555-566

Methanesulphonate in the firn of King George Island, Antarctica, 589-594

A new ice-core record from Lomonosovfonna, Svalbard: viewing the 1920-97 data in relation to present climate and environmental conditions, 335-345

Oxygen isotopic and soluble ionic composition of a shallow firn core, Inilchek glacier, central Tien Shan, 548-554

Ivask, J., see Isaksson, E. and others

Iverson, N. R. and R. M. Iverson, (paper: Distributed shear of subglacial till due to Coulomb slip) 481-488

Iverson, R. M., see Iverson, N. R.

Jauhiainen, T., see Isaksson, E. and others

Jenkins, A., see Corr, H. F. J. and others

Jespersen, M. N., see Winther, J.-G. and others

Jiskoot, H., A. K. Pedersen and T. Murray, (paper: Multi-model photogrammetric analysis of the 1990s surge of Sortebræ, East Greenland) 677-687

John Evans Glacier (Canada):

Mapping thermal and hydrological conditions beneath a polythermal glacier with radio-echo sounding, 232-242

Jökulhlaups:

Correspondence, 517-518

Growth and drainage of supraglacial lakes on the debris-mantled Ngozumpa Glacier, Khumbu Himal, Nepal, 626-638

Prevention of outburst floods from periglacial lakes at Grubengletscher, Valais, Swiss Alps, 111-122

Jonsson, P., see Hvidberg, C. S. and others

Jordan, E., see Ramírez, E. and others

Joughin, I. R., see Price, S. F. and others

Jungfraufirn (Switzerland):

Cold firn and ice of high-altitude glaciers in the Alps: measurements and distribution modelling, 85-96

Kameda, T., see Shiraiwa, T. and others

Kang Shichang, Qin Dahe, P. A. Mayewski and C. P.Wake, (correspondence: Recent 180 years oxalate $\left(\mathrm{C}_{2} \mathrm{O}_{4}{ }^{2-}\right)$ records recovered from the Mount Everest ice core: some environmental implications) $155-156$

Kang Shichang, Qin Dahe, P. A. Mayewski, Xie Shucheng and Duan Keqin, (correspondence: Evidence of the Kuwaiti oil fires in the Dasuopu glacier ice core, central Himalaya) 519-520

Karlén, W., see Isaksson, E. and others

Karlöf, L., see Isaksson, E. and others

Kaser, G., (paper: Glacier-climate interaction at low latitudes) 195-204

Kavanaugh, J. L. and G. K. C. Clarke, (paper: Abrupt glacier motion and reorganization of basal shear stress following the establishment of a connected drainage system) 472-480

Keller, K., see Hvidberg, C. S. and others

Kenya:

Glacier-climate interaction at low latitudes, 195-204

Khazendar, A., J.-L. Tison, B. Stenni, M. Dini and A. Bondesan, (paper: Significant marine-ice accumulation in the ablation zone beneath an Antarctic ice shelf) 359-368

King, J. C., P. S. Anderson and G.W. Mann, (paper: The seasonal cycle of sublimation at Halley, Antarctica) 1-8

Knight, P. G., (review: Maltman, A. J., B. Hubbard and M. J. Hambrey, eds. 2000. Deformation of glacial materials), 163-164

Knudsen, N. T., see König, M. and others

Kongsvegen (Svalbard):

Tidewater glacier beds: insights from iceberg debris in Kongsfjorden, Svalbard, 295-302 
Kreutz, K. J., V. B. Aizen, L. DeW. Cecil and C. P. Wake, (paper: Oxygen isotopic and soluble ionic composition of a shallow firn core, Inilchek glacier, central Tien Shan) 548-554

Krimmel, R. M., see Elsberg, D. H. and others

Kronebreen (Svalbard):

Tidewater glacier beds: insights from iceberg debris in Kongsfjorden, Svalbard, 295-302

Kwok, R., see Nghiem, S. V. and others

Kyrgyzstan:

Oxygen isotopic and soluble ionic composition of a shallow firn core, Inilchek glacier, central Tien Shan, 548-554

Kääb, A., see Haeberli, W. and others

König, M., J.-G. Winther, N.T. Knudsen and T. Guneriussen, (paper: Firnline detection on Austre Okstindbreen, Norway, with airborne multipolarization SAR) 251-257

Lambert Glacier (Antarctica): Correspondence, 160-162

Larson, G. J., see Ensminger, S. L. and others

Laternser, M., see Suter, S. and others

Lawson, D. E., see Ensminger, S. L. and others

Le Meur, E. and R. C. A. Hindmarsh, (paper: Coupled marine-ice-sheet/ Earth dynamics using a dynamically consistent ice-sheet model and a self-gravitating viscous Earth model) 258-270

Le Meur, E., see Hindmarsh, R. C. A.

LeConte Glacier (U.S.A.):

Short-term flow dynamics of a retreating tidewater glacier: LeConte Glacier, Alaska, U.S.A., 567-578

Leppäranta, M., (review: Wadhams, Peter. 2000. Ice in the ocean) 523

Letréguilly, A., see Six, D. and others

Li Hongqin, see Xiao Cunde and others

Li Yingkui, Liu Gengnian and Cui Zhijiu, (paper: Longitudinal variations in cross-section morphology along a glacial valley: a case-study from the Tien Shan, China) 243-250

Lichey, C. and H. H. Hellmer, (paper: Modeling giant-iceberg drift under the influence of sea ice in the Weddell Sea, Antarctica) 452-460

Liston, G. E., seeWinther, J.-G. and others

Liu Gengnian, see Li Yingkui and others

Lomonosovfonna (Svalbard):

A new ice-core record from Lomonosovfonna, Svalbard: viewing the 1920-97 data in relation to present climate and environmental conditions, 335-345

Lowe, A. L., see Wellner, J. S. and others

Lüthi, M. P. and M. Funk, (paper: Modelling heat flow in a cold, high-altitude glacier: interpretation of measurements from Colle Gnifetti, Swiss Alps) 314-324

MacAyeal, D. R., see Schmeltz, M. and others

Mair, D., P. Nienow, I. Willis and M. Sharp, (paper: Spatial patterns of glacier motion during a high-velocity event: Haut Glacier d'Arolla, Switzerland) 9-20

Mann, G. W., see King, J. C. and others

Martma, T., see Isaksson, E. and others

Mass balance:

Anomalous heat and mass budget of Glaciar Zongo, Bolivia, during the 1997/98 El Niño year, 21-28

Correspondence, 157-158

Estimating South Cascade Glacier (Washington, U.S.A.) mass balance from a distant radiosonde and comparison with Blue Glacier, 579-588

Greenland ice-sheet mass-balance distribution: a variance analysis of existing field data, 441-451

Meteorological conditions over Antarctic blue-ice areas and their influence on the local surface mass balance, 37-50

On the characterization of glacier response by a single time-scale, 659-664
Quantifying the effects of climate and surface change on glacier mass balance, 649-658

The surges of Variegated Glacier, Alaska, U.S.A., and their connection to climate and mass balance, 351-358

Terminus behavior and response time of North Cascade glaciers, Washington, U.S.A., 497-506

Matanuska Glacier (U.S.A.):

Basal-crevasse-fill origin of laminated debris bands at Matanuska Glacier, Alaska, U.S.A., 412-422

Mayewski, P. A., see Isaksson, E. and others

Mayewski, P. A., see Han Jiankang and others

Mayewski, P. A., see Kang Shichang and others

Meijer, H. A. J., see Isaksson, E. and others

Melvold, K., see Pinglot, J. F. and others

Mendoza, J., see Ramírez, E. and others

Moore, J. C., see Isaksson, E. and others

Moore, J. C., (review: Alley, Richard B. 2000. The two-mile time machine: ice cores, abrupt climate change, and our future) 524

Motyka, R. J., see O’Neel, S. and others

Mulvaney, R., see Isaksson, E. and others

Murav'yev, Y. D., see Shiraiwa, T. and others

Murray Ice Cap (Canada):

Correspondence, 154

Murray, T., see Fowler, A. C. and others

Murray, T., see Jiskoot, H. and others

Murray, T., see Porter, P. R.

Naruse, R., see Iizuka, Y. and others

Nef, Glaciar (Chile):

Buoyancy-driven lacustrine calving, Glaciar Nef, Chilean Patagonia, $135-146$

Nepal:

Growth and drainage of supraglacial lakes on the debris-mantled Ngozumpa Glacier, Khumbu Himal, Nepal, 626-638

Nereson, N. A. and C. F. Raymond, (paper: The elevation history of ice streams and the spatial accumulation pattern along the Siple Coast of West Antarctica inferred from ground-based radar data from three inter-ice-stream ridges) 303-313

Ng, F. S. L., see Fowler, A. C. and others

Nghiem, S. V., K. Steffen, R. Kwok and W.-Y. Tsai, (paper: Detection of snowmelt regions on the Greenland ice sheet using diurnal backscatter change) 539-547

Ngozumpa Glacier (Nepal):

Growth and drainage of supraglacial lakes on the debris-mantled

Ngozumpa Glacier, Khumbu Himal, Nepal, 626-638

Nienow, P., see Mair, D. and others

Nishio, F., see Shiraiwa, T. and others

Norway:

Correspondence, 517-518

Firn-line detection on Austre Okstindbreen, Norway, with airborne multipolarization SAR, 251-257

The isotopic record at an alpine glacier and its implications for local climatic changes and isotopic homogenization processes, 147-151

O’Neel, S., K. A. Echelmeyer and R. J. Motyka, (paper: Short-term flow dynamics of a retreating tidewater glacier: LeConte Glacier, Alaska, U.S.A.) $567-578$

Oerlemans, J., see Greuell, W. and others

Ovsyannikov, A. A., see Shiraiwa, T. and others

Patagonia:

Buoyancy-driven lacustrine calving, Glaciar Nef, Chilean Patagonia, 135-146 
Pedersen, A. K., see Jiskoot, H. and others

Pelto, M. S. and C. Hedlund, (paper: Terminus behavior and response time of North Cascade glaciers, Washington, U.S.A.) 497-506

Photogrammetry:

Multi-model photogrammetric analysis of the 1990s surge of Sortebræ, East Greenland, 677-687

Pine Island Glacier (Antarctica):

Investigations of an "ice-plain" in the mouth of Pine Island Glacier, Antarctica, 51-57

Pinglot, J. F., see Isaksson, E. and others

Pinglot, J. F., J. O. Hagen, K. Melvold, T. Eiken and C. Vincent, (paper: A mean net accumulation pattern derived from radioactive layers and radar soundings on Austfonna, Nordaustlandet, Svalbard) 555-566

Pohjola, V., see Isaksson, E. and others

Porter, P. R. and T. Murray, (paper: Mechanical and hydraulic properties of till beneath Bakaninbreen, Svalbard) 167-175

Pouyaud, B., see Ramírez, E. and others

Price, S. F. and I. M. Whillans, (paper: Crevasse patterns at the onset to Ice Stream B, West Antarctica) 29-36

Price, S. F., R. A. Bindschadler, C. L. Hulbe and I. R. Joughin, (paper: Post-stagnation behavior in the upstream regions of Ice Stream C, West Antarctica) 283-294

Qin Dahe, see Kang Shichang and others

Qin Dahe, see Xiao Cunde and others

Radar:

Internal ice-sheet radar layer profiles and their relation to reflection mechanisms between Dome $\mathrm{C}$ and the Transantarctic Mountains, 205-212

Investigations of an "ice-plain" in the mouth of Pine Island Glacier, Antarctica, 51-57

Mapping thermal and hydrological conditions beneath a polythermal glacier with radio-echo sounding, 232-242

A mean net accumulation pattern derived from radioactive layers and radar soundings on Austfonna, Nordaustlandet, Svalbard, 555-566

Ramírez, E., B. Francou, P. Ribstein, M. Descloitres, R. Guérin, J. Mendoza, R. Gallaire, B. Pouyaud and E. Jordan, (paper: Small glaciers disappearing in the tropical Andes: a case-study in Bolivia: Glaciar Chacaltaya $\left(16^{\circ}\right.$ S)) $187-194$

Rasmussen, L. A. and H. Conway, (paper: Estimating South Cascade Glacier (Washington, U.S.A.) mass balance from a distant radiosonde and comparison with Blue Glacier) 579-588

Raymond, C. F., see Eisen, O. and others

Raymond, C. F., see Nereson, N. A.

Reijmer, C. H., see Bintanja, R.

Remote sensing:

Blue-ice areas in Antarctica derived from NOAA AVHRR satellite data, 325-334

Detection of snowmelt regions on the Greenland ice sheet using diurnal backscatter change, 539-547

Firn-line detection on Austre Okstindbreen, Norway, with airborne multipolarization SAR, 251-257

Post-stagnation behavior in the upstream regions of Ice Stream C, West Antarctica, 283-294

Ren Jiawen, see Xiao Cunde and others

Reviews:

Alley, Richard B. 2000. The two-mile time machine: ice cores, abrupt climate change, and our future, 524

Alley, Richard B. and Robert A. Bindschadler, eds. 2001. The West Antarctic ice sheet: behavior and environment, 521-522

Jones, H. G., J.W. Pomeroy, D. A. Walker and R.W. Hoham, eds., 2001. Snow ecology: an interdisciplinary examination of snow-covered ecosystems, 347

Maltman, A. J., B. Hubbard and M. J. Hambrey, eds. 2000. Deformation of glacial materials, 163-164

Wadhams, Peter. 2000. Ice in the ocean, 523

Reynaud, L., see Six, D. and others
Ribstein, P., see Ramírez, E. and others

Ribstein, P., see Wagnon, P. and others

Rignot, E., (paper: Evidence for rapid retreat and mass loss of Thwaites Glacier, West Antarctica) 213-222

Rignot, E., see Schmeltz, M. and others

Rott, H., see Björnsson, H. and others

Russia:

Characteristics of a crater glacier at Ushkovsky volcano, Kamchatka, Russia, as revealed by the physical properties of ice cores and borehole thermometry, 423-432

Ruwenzori:

Glacier-climate interaction at low latitudes, 195-204

Salamatin, A. N., see Shiraiwa, T. and others

SAR:

Firn-line detection on Austre Okstindbreen, Norway, with airborne multipolarization SAR, 251-257

Glacier-volcano interactions deduced by SAR interferometry, 58-70

Post-stagnation behavior in the upstream regions of Ice Stream C, West Antarctica, 283-294

Satake, H., see Iizuka, Y. and others

Scherer, D., see Arck, M.

Schmeltz, M., E. Rignot and D. R. MacAyeal, (paper: Ephemeral grounding as a signal of ice-shelf change) $71-77$

Sharp, M., see Copland, L.

Sharp, M., see Mair, D. and others

Shi Yafeng, see He Yuanqing and others

Shipp, S. S., see Wellner, J. S. and others

Shiraiwa, T., see Iizuka, Y. and others

Shiraiwa, T., Y. D. Murav'yev, T. Kameda, F. Nishio, Y. Toyama, A. Takahashi, A. A. Ovsyannikov, A. N. Salamatin and K. Yamagata, (paper: Characteristics of a crater glacier at Ushkovsky volcano, Kamchatka, Russia, as revealed by the physical properties of ice cores and borehole thermometry) $423-432$

Sicart, J. E., seeWagnon, P. and others

Siegel, A., see Björnsson, H. and others

Siegert, M. J. and S. Fujita, (paper: Internal ice-sheet radar layer profiles and their relation to reflection mechanisms between Dome $\mathrm{C}$ and the Transantarctic Mountains) 205-212

Siegert, M. J., (correspondence: Comments on "Calculating basal thermal zones beneath the Antarctic ice sheet" by Wilch and Hughes) 159-160

Siple Dome (Antarctica):

The elevation history of ice streams and the spatial accumulation pattern along the Siple Coast of West Antarctica inferred from groundbased radar data from three inter-ice-stream ridges, 303-313

Six, D., A. Letréguilly and L. Reynaud, (paper: Greenland ice-sheet massbalance distribution: a variance analysis of existing field data) 441-451

Smedsrud, L. H., (paper: Frazil-ice entrainment of sediment: large-tank laboratory experiments) 461-471

Snow:

Detection of snowmelt regions on the Greenland ice sheet using diurnal backscatter change, 539-547

A high-altitude snow chemistry record from Amundsenisen, Dronning Maud Land, Antarctica, 489-496

Numerical modeling of blowing and drifting snow in Alpine terrain, 97-110

A physically based method for correcting temperature data measured by naturally ventilated sensors over snow, $665-670$

Review. Jones, H. G., J.W. Pomeroy, D. A. Walker and R. W. Hoham eds., 2001. Snow ecology: an interdisciplinary examination of snowcovered ecosystems, 347

Spatial patterns of snow stability throughout a small mountain range, 176-186

Surface properties and processes of perennial Antarctic sea ice in summer, 613-625 
Sortebræ (Greenland):

Multi-model photogrammetric analysis of the 1990s surge of Sortebræ, East Greenland, 677-687

South Cascade Glacier (U.S.A.):

On the characterization of glacier response by a single time-scale, 659-664

Estimating South Cascade Glacier (Washington, U.S.A.) mass balance from a distant radiosonde and comparison with Blue Glacier, 579-588

Quantifying the effects of climate and surface change on glacier mass balance, 649-658

Spencer, M. K., R. B. Alley and T.T. Creyts, (paper: Preliminary firndensification model with 38-site dataset) 671-676

Steffen, K., see Nghiem, S. V. and others

Stenni, B., see Khazendar, A. and others

Sturm, M., (review: Jones, H. G., J.W. Pomeroy, D. A. Walker and R.W. Hoham (eds.), 2001. Snow ecology: an interdisciplinary examination of snow-covered ecosystems) 347

Sublimation:

The seasonal cycle of sublimation at Halley, Antarctica, 1-8

Sun Weizhen, see Xiao Cunde and others

Surges:

Multi-model photogrammetric analysis of the 1990s surge of Sortebræ, East Greenland, 677-687

The surges of Variegated Glacier, Alaska, U.S.A., and their connection to climate and mass balance, $351-358$

Thermally controlled glacier surging, 527-538

Suter, S., M. Laternser, W. Haeberli, R. Frauenfelder and M. Hoelzle, (paper: Cold firn and ice of high-altitude glaciers in the Alps: measurements and distribution modelling) 85-96

Svalbard:

Enhancement of glacial solute fluxes in the proglacial zone of a polythermal glacier, 378-386

Flow dynamics of tidewater glaciers: a numerical modelling approach, 595-606

A mean net accumulation pattern derived from radioactive layers and radar soundings on Austfonna, Nordaustlandet, Svalbard, 555-566

Mechanical and hydraulic properties of till beneath Bakaninbreen, Svalbard, 167-175

A new ice-core record from Lomonosovfonna, Svalbard: viewing the 1920-97 data in relation to present climate and environmental conditions, 335-345

Thermally controlled glacier surging, 527-538

Tidewater glacier beds: insights from iceberg debris in Kongsfjorden, Svalbard, 295-302

Sweden:

A physically based method for correcting temperature data measured by naturally ventilated sensors over snow, 665-670

Switzerland:

Cold firn and ice of high-altitude glaciers in the Alps: measurements and distribution modelling, 85-96

Modelling heat flow in a cold, high-altitude glacier: interpretation of measurements from Colle Gnifetti, Swiss Alps, 314-324

Numerical modeling of blowing and drifting snow in Alpine terrain, 97-110

Prevention of outburst floods from periglacial lakes at Grubengletscher, Valais, Swiss Alps, 111-122

Spatial patterns of glacier motion during a high-velocity event: Haut Glacier d'Arolla, Switzerland, 9-20

Takahashi, A., see Shiraiwa, T. and others

\section{Temperature measurement:}

A physically based method for correcting temperature data measured by naturally ventilated sensors over snow, 665-670

Characteristics of a crater glacier at Ushkovsky volcano, Kamchatka, Russia, as revealed by the physical properties of ice cores and borehole thermometry, 423-432

Modelling heat flow in a cold, high-altitude glacier: interpretation of measurements from Colle Gnifetti, Swiss Alps, 314-324

Teysseire, P., see Haeberli, W. and others

Theakstone, W. H., (correspondence: Fracturing and sediment deposition at the glacier surface by jökulhlaups: a common occurrence) 517-518

Theakstone, W. H., see He Yuanqing and others
Thomas, D. N., see Haas, C. and others

Thomassen, M., see Isaksson, E. and others

Thorsteinsson, T., (paper: An analytical approach to deformation of anisotropic ice-crystal aggregates) 507-516

Thwaites Glacier (Antarctica):

Ephemeral grounding as a signal of ice-shelf change, 71-77

Evidence for rapid retreat and mass loss of Thwaites Glacier, West Antarctica, 213-222

Tien Shan:

Longitudinal variations in cross-section morphology along a glacial valley: a case-study from the Tien Shan, China, 243-250

Oxygen isotopic and soluble ionic composition of a shallow firn core, Inilchek glacier, central Tien Shan, 548-554

Subglacial deformation: evidence from microfabric studies of particles and voids in till from the upper Ürümqi river valley, Tien Shan, China, 607-612

Till:

Distributed shear of subglacial till due to Coulomb slip, 481-488

Implications of till deformation on glacier dynamics, 123-134

Mechanical and hydraulic properties of till beneath Bakaninbreen, Svalbard, 167-175

Subglacial deformation: evidence from microfabric studies of particles and voids in till from the upper Ürümqi river valley, Tien Shan, China, 607-612

Tison, J.-L., see Khazendar, A. and others

Toyama, Y., see Shiraiwa, T. and others

Tranter, M., seeWadham, J. L. and others

Trapridge Glacier (Canada):

Abrupt glacier motion and reorganization of basal shear stress following the establishment of a connected drainage system, 472-480

Thermally controlled glacier surging, 527-538

Truffer, M., K. A. Echelmeyer and W. D. Harrison, (paper: Implications of till deformation on glacier dynamics) 123-134

Tsai, W.-Y., see Nghiem, S. V. and others

Twickler, M., see Isaksson, E. and others

Twickler, M. S., see Han Jiankang and others

U.S.A.:

Basal-crevasse-fill origin of laminated debris bands at Matanuska Glacier, Alaska, U.S.A., 412-422

Estimating South Cascade Glacier (Washington, U.S.A.) mass balance from a distant radiosonde and comparison with Blue Glacier, 579-588 Implications of till deformation on glacier dynamics, 123-134

On the characterization of glacier response by a single time-scale, 659-664

Quantifying the effects of climate and surface change on glacier mass balance, $649-658$

Short-term flow dynamics of a retreating tidewater glacier: LeConte Glacier, Alaska, U.S.A., 567-578

Spatial patterns of snow stability throughout a small mountain range, 176-186

Terminus behavior and response time of North Cascade glaciers, Washington, U.S.A., 497-506

The surges of Variegated Glacier, Alaska, U.S.A., and their connection to climate and mass balance, 351-358

Uruashraju, Glaciar (Peru):

Glacier-climate interaction at low latitudes, 195-204

Vaikmäe, R., see Isaksson, E. and others

Van de Wal, R. S.W., see Greuell, W. and others

Van de Wal, R. S. W., see Isaksson, E. and others

Van den Broeke, M. R., see Isaksson, E. and others

Van der Veen, C. J., see Whillans, I. M.

Variegated Glacier (U.S.A.):

The surges of Variegated Glacier, Alaska, U.S.A., and their connection to climate and mass balance, $351-358$

Vatnajökull (Iceland):

Glacier-volcano interactions deduced by SAR interferometry, 58-70 
Vaughan, D. G., see Corr, H. F. J. and others

Vieli, A., M. Funk and H. Blatter, (paper: Flow dynamics of tidewater glaciers: a numerical modelling approach) 595-606

Vincent, C., see Pinglot, J. F. and others

Volcanoes:

Glacier-volcano interactions deduced by SAR interferometry, 58-70

Vonder Mühll, D., see Haeberli, W. and others

Waddington, E. D., J. F. Bolzan and R. B. Alley, (paper: Potential for stratigraphic folding near ice-sheet centers) 639-648

Wadham, J. L., R. J. Cooper, M. Tranter and R. Hodgkins, (paper: Enhancement of glacial solute fluxes in the proglacial zone of a polythermal glacier) 378-386

Wagnon, P., P. Ribstein, B. Francou and J. E. Sicart, (paper: Anomalous heat and mass budget of Glaciar Zongo, Bolivia, during the 1997/98 El Niño year) 21-28

Wake, C. P., see Gerasimoff, M. D.

Wake, C. P., see Kang Shichang and others

Wake, C. P., see Kreutz, K. J. and others

Warren, C., D. Benn, V. Winchester and S. Harrison, (paper: Buoyancydriven lacustrine calving, Glaciar Nef, Chilean Patagonia) 135-146

Warren, C., D. Benn, V. Winchester and S. Harrison, (Erratum: Buoyancydriven lacustrine calving, Glaciar Nef, Chilean Patagonia) 348

Weddell Sea (Antarctica):

Modeling giant-iceberg drift under the influence of sea ice in the Weddell Sea, Antarctica, 452-460

Surface properties and processes of perennial Antarctic sea ice in summer, 613-625

Wellner, J. S., A. L. Lowe, S. S. Shipp and J. B. Anderson, (paper: Distribution of glacial geomorphic features on the Antarctic continental shelf and correlation with substrate: implications for ice behavior) 397-411
Whillans, I. M. and C. J. van der Veen, (paper: Transmission of stress between an ice stream and interstream ridge) 433-440

Whillans, I. M., see Price, S. F.

Whillans Ice Stream (Antarctica), see Ice Stream B

Whitlow, S., see Isaksson, E. and others

Willis, I., see Mair, D. and others

Winchester, V., see Warren, C. and others

Winther, J.-G., see König, M. and others

Winther, J.-G., M. N. Jespersen and G. E. Liston, (paper: Blue-ice areas in Antarctica derived from NOAA AVHRR satellite data) 325-334

Wiseman, S., see Benn, D. I. and others

Xiao Cunde, Ren Jiawen, Qin Dahe, Li Hongqin, Sun Weizhen and I. Allison, (correspondence: Complexity of the climatic regime over the Lambert Glacier basin of the East Antarctic ice sheet: firn-core evidences) 160-162

Xie Shucheng see Kang Shichang and others

Xie Zichu, see Han Jiankang and others

Yamagata, K., see Shiraiwa, T. and others

Yao Tandong, see He Yuanqing and others

Yi Chaolu and Cui Zhijiu, (paper: Subglacial deformation: evidence from microfabric studies of particles and voids in till from the upper Ürümqi river valley, Tien Shan, China) 607-612

Zhang Xinping, see Han Jiankang and others

Zongo, Glaciar (Bolivia):

Anomalous heat and mass budget of Glaciar Zongo, Bolivia, during the 1997/98 El Niño year, 21-28 